\title{
VAGINITIS GONORE PADA ANAK
}

\author{
Judith Yapari \\ Herry E. J. Pandaleke
}

\author{
Bagian Ilmu Kesehatan Kulit dan Kelamin \\ Fakultas Kedokteran Universitas Sam Ratulangi Manado \\ Email: yaparijudith@gmail.com
}

\begin{abstract}
Gonorrhoeae is a common human sexually transmitted infection caused by Neisseria gonorrhoeae. Vaginitis gonorrhoeae is a gonorrhoeae infection which commonly occurs in children after the neonatal period. Its manifestation in girls can be asymptomatic as well as some urethral or vaginal discharge. A Gram staining, culture and a serologic test should be performed for confirming the diagnosis. A gonorrhoeae suspected case in prepubertal girls may lead to a sexual abuse. We reported a 9-year-old girl complaining yellowish and large amount leukorrhea since 3 weeks ago. The Gram stain showed intracellular and extracellular negative Gram diplococcus with abundance of polymorphonuclear leucocytes $>30 /$ high magnification. Treatment with a single dose of cefixime $200 \mathrm{mg}$ orally showed significant improvement aftter 3 days. Conclusion: A case of vaginitis gonorrhoeae was established based on the anamnesis, physical examination, and laboratory test. Treatment with a single dose of cefixime gave a satisfactory result.
\end{abstract}

Keywords: vaginitis gonorrhoeae, Neisseria gonorrhoeae, cefixime

\begin{abstract}
Abstrak: Gonore merupakan penyakit infeksi menular seksual yang disebabkan oleh kuman Neisseria gonorrhoeae. Vaginitis gonore merupakan bentuk gonore pada anak yang paling sering terjadi setelah masa neonatus. Manifestasi klinis infeksi gonore pada anak perempuan dapat asimtomatik maupun simtomatik berupa adanya duh tubuh dari uretra dan vagina, yang meninggalkan bekas di celana dalam. Pemeriksaan penunjang yang dapat dilakukan ialah pewarnaan Gram, kultur, dan tes serologik. Bila dicurigai adanya infeksi gonore pada anak perempuan prapubertas maka kekerasan atau pelecehan seksual harus dipikirkan. Kami melaporkan satu kasus vaginitis gonore pada seorang anak perempuan berusia 9 tahun dengan keluhan keputihan berwarna kuning kental dalam jumlah cukup banyak sejak 3 minggu lalu. Pada pewarnaan Gram didapatkan kuman diplokokus intrasel dan ekstrasel serta leukosit PMN >30/LPB. Perbaikan signifikan terlihat dalam 3 hari setelah pemberian terapi sefiksim $200 \mathrm{mg}$ dosis tunggal. Simpulan: Telah dilaporkan kasus vaginitis gonore dengan diagnosis berdasarkan anamnesis, pemeriksaan fisik, dan pemeriksaan penunjang. Terapi sefiksim dosis tunggal memberikan hasil yang memuaskan.
\end{abstract}

Kata kunci: vaginitis gonore, Neisseria gonorrhoeae, sefiksim

Gonore mencakup semua penyakit yang disebabkan oleh Neisseria gonorrhoeae. Gonore disebabkan oleh Neisseria gonorrhoeae yang ditemukan oleh Neiser pada tahun 1879 dan kemudian diumumkan pada tahun $1882 .^{1}$

Gonokokus termasuk golongan diplokokus berbentuk biji kopi dengan lebar 0,8 $\mu$, panjang 1,6 $\mu$ dan tahan asam. Kuman ini bersifat gram negatif, terlihat di luar atau di dalam sel polimorfonuklear, tidak tahan lama di udara bebas, cepat mati pada keadaan kering, tidak tahan suhu di atas $39^{\circ} \mathrm{C}$, dan tidak tahan terhadap desinfektan. ${ }^{2,3}$ Insiden infeksi menular seksual di tiap 